\title{
BREAKING NEW GROUND IN THE THEORY AND PRACTICE OF HISTORICAL LEXICOGRAPHY
}

\author{
VASYL GRESHCHUK
}

Dydyk-Meush H. Kombinatoryka v ukrainskii movi XVI-XVIII stolit: teoriia, praktyka, slovnyk. Lviv, Instytut ukrainoznavstva im. I. Krypiakevycha, Naukove tovarystvo im. Shevchenka, 2018.

The linguistic issues of valence, combinability, distribution, and position of language units emerged during the last century; and to date, most of the theoretical and practical aspects have been explored, albeit not exhaustively. Modern linguistics has accumulated a significant body of research on syntagmatic relations at all levels of language structure. The valence of language units has mainly been explored from the synchronic perspective. As regards old languages available only in written form, the above-mentioned issues have been studied sporadically, if at all. H. Dydyk-Meush makes a rather successful attempt to apply novel methods of analyzing combinability to the written Ukrainian language of the 16th-18th centuries. Thus the topicality of the research arises from the subject matter chosen as well as from the need to conduct a comprehensive analysis of valence in the 16th-18thcentury written Ukrainian language, which can contribute to further systemic research on the combinability of language units in the old Ukrainian language.

As determined by the subject matter of the monograph, the author discusses the periodization of the Ukrainian language, analyzes trends in studying the Ukrainian language of the 16th-18th centuries, characterizes old Ukrainian records of the period in question from various perspectives, with the main emphasis being on combinability. The researcher provides cogent arguments to support her theoretical generalizations about the Ukrainian language of the 16th-18th centuries as an object of linguistic analysis and the possibility of applying novel linguistic methods to old Ukrainian texts within the context of the theory of usus.

H. Dydyk-Meush's paper is centered around the theoretical and practical aspects of combinability, valence. The author interprets valence as the ability of equal-level units (first and foremost, that of words) to combine with each other, and she differentiates between valence in language and valence in speech, which are not always congruent. Combinability is regarded as a particular manifestation of this property of the word in discourse, so it can be studied by analyzing language data. Valence and combinability are interconnected and interdependent, with combinability being interpreted as valence realized in speech. The author provides a thorough, comprehensive analysis of types of combinability syntactic, lexical, stylistic. In addition, the monograph regards combinability as a cognitive phenomenon: it discusses lexical combinability in general and explores adjective-noun collocations in the 16th-18th-century Ukrainian language from a cognitive linguistics perspective. Since contexts 
normally help to identify various types of combinability, they are characterized from various perspectives. Due consideration is also given to distribution, which is viewed within the context of combinatorial linguistics.

The author provides a detailed description of adjective-noun collocations obtained from Ukrainian texts of the 16th-18th centuries with an emphasis on their nominative characteristics, structure, and functions in text and discourse, as well as the semantic functions and communicative potential of their components. The paper also explores an attributive adjective as part of an adjective-noun collocation and argues that it serves as a means of nomination, evaluation, intensification and delimitation. An attributive adjective also performs the functions of qualification and restriction since it imposes selection restrictions on the noun in an adjective-noun collocation. Having analyzed a corpus of Ukrainian texts dating back to the 16th-18th centuries, the author suggests a bold and, most importantly, well-substantiated argument against attaching secondary importance to an adjective in a text. Having identified the status of adjective-noun collocations in the context of connections between their components, the author argues that adjectives and adjective-noun collocations are on a par with head nouns in terms of nominating people, objects, phenomena, etc.

Particularly worthy of attention are the discourse characteristics of adjectives, which were identified by analyzing all the speech situations connected with attributive adjectives used in their main functions in a corpus of 550 texts of various genres, with each excerpt containing 100-200 words. This allowed for the possibility of giving a detailed description of adjectives as part of adjective-noun collocations and whole texts from three perspectives: 1) the major (primary or secondary) functions of de-adjectival nouns; 2 ) the textual potential of adjectives; 3 ) combinability and position in a series of attributive adjectives.

The main contribution of this research is that the corpus of adjective-noun collocations selected from Ukrainian texts of the 16th-18th centuries is described from the perspectives of linguistic anthropology and cognitive linguistics. The cognitive approach to analyzing the semantic and combinatorial properties of the above-mentioned adjective-noun collocations allowed for the possibility of showing which substantive elements were the most significant for the religious and theological texts of the 16th-18th centuries; these include, among others, сердияе (heart), душа (soul), умыссель (intent), въра (faith), надъя (hоре), любовъ (love), Бог (God), церков (church), человек (man). The glossaries of adjectives created for each of the nouns were then used to model a semantic basis of attributive adjectives and to support the claim that they are heads of such word groups and also the means with the help of which language "preserves and reproduces the basic cultural and religious, Christian, concepts of Ukrainians for a long time" [1, p.268].

Another important contribution is the analysis of adjective-noun collocations in accordance with a scale of combinatorial semantics, which is based on the principle of the integration of senses depending on the degree of deducibility/non-deducibility of the combinatorial semantics of a word group from the sum of the meanings of its components. As a result, the author gives a detailed description of a whole variety of adjective-noun combinations with an emphasis on transitional adjective-noun collocations defined as being on the borderline between fully free and fully bounded collocations. Compositional and non-compositional word groups are both regarded as transitional. Compositional adjective-noun collocations can be compositionally free or linguistically bound, with the latter being classified into the following types: nominative, etiquettical, clichéd, traditionally epithetical, and stereotypical phrases. Non-compositional adjective-noun combinations are divided into modifications, imitations, oxymorons, annulments, falsifications, and periphrases.

As seen from the data provided in the monograph, the adjective-noun collocations found in the Ukrainian records of the 16th-18th centuries can be a rewarding and reliable material for lexicographic description. This is confirmed in the final chapter, which highlights the foundational principles of compiling "A Combinatorial Dictionary of the Ukrainian Language of the 16th-18th centuries" and presents a sample of such a dictionary for entries beginning with the letters $A$ and 5 . The dictionary combines the features of a historical and a combinatorial dictionary of 16th-18th-century adjective-noun collocations, thus being an innovative lexicographic study. 
Therefore, the paper under review breaks new ground in Ukrainian linguistics by presenting a comprehensive analysis of adjective-noun collocations obtained from Ukrainian records of the 16th18th centuries from the perspective combinatorial linguistics, which has dominated the research agenda over the last few decades. The author of the monograph extrapolates the techniques and methods of the modern anthropocentric research paradigm, particularly those of linguistic anthropology and cognitive linguistics, to the traditional framework for studying combinatorial properties of words, which allows for the possibility of extending our knowledge of the combinability of an adjective with a noun in 16th18th-century Ukrainian texts of various genres. While we acknowledge that the research provides a comprehensive analysis of an extensive corpus of adjective-noun collocations representative of the Ukrainian language of the 16th-18th centuries, thus making a significant contribution to Ukrainian linguistics, we consider some of the issues to be ambiguous or debatable.

The author's conception of a combinatorial dictionary of the Ukrainian language of the 16th-18th centuries is based exclusively on adjective-noun collocations. However, all the other types of word groups are no less interesting from the perspectives of combinatorial semantics, linguistic anthropology, and cognitive linguistics. It is obvious that the specifics of the other types of word groups will determine the lexicographic principles for describing combinability; therefore, we strongly believe that a combinatorial dictionary of a language of a certain period must result from a comprehensive analysis of all types of word groups, so the dictionary suggested in the monograph requires a more accurate title.

The monograph makes relevant use of an impressive body of research literature, with appropriate citations provided. In some cases, however, the text is burdened with excessively long citations from a single source (for instance I.Franko, L.Humetska) or a string of citations from different sources, so the author's idea becomes unclear. This criticism refers to the author's writing style rather than the content of her ideas.

The glossaries presented in the monograph comply with research standards; however, some of the definitions need correction. To illustrate, the adjective каменный (stony), which is exemplified by каменное сердие (stony heart), is incorrectly defined as "rooted in sin", "soulless, stony"; instead of that, the semantic description could have been complemented with the adjective insensitive. The adjective тягхий (draft - of animals used for pulling heavy loads) is repeated in its definition, which should have been avoided since the Ukrainian тяглий is a dialectal word.

It is laudable that the author provides a meticulous, scientifically rigorous classification of adjective-noun collocations used in the Ukrainian language of the 16th-18th centuries; however, it is doubtful that the word group свъжый небожиикъ (a fresh dead body), which is listed among apparent охуmorons such аs старый младенецъ (an old пешborn), горкая радость (bitter joy), горкое веселие (bitter fun), etc., might be regarded as an oxymoron since свъжый (fresh) does not mean живий (living).

However, the above-mentioned criticisms and suggestions cannot outweigh the significance of this paper. H. Dydyk-Meush's monograph is a novel piece of research, the first of its kind in Ukrainian linguistics; it examines the combinability of an adjective with a noun in the Ukrainian language of the 16th-18th centuries. The novelty is that the author suggests a number of new research techniques and methodological frameworks such as a scale of combinatorial semantics for analyzing combinability from a diachronic perspective, foundational principles of compiling an innovative combinatorial dictionary of adjective-noun collocations used in the Ukrainian language of the 16th-18th centuries.

The research has significant theoretical and practical implications. The theoretical assumptions about the combinatorial regularities of words in 16th-18th-century Ukrainian texts of various genres, the scientific principles of compiling a combinatorial dictionary of the Ukrainian language of the period in question, and the conclusions suggested make a remarkable contribution to the development of combinatorial lexicology and lexicography. The findings enrich modern Ukrainian linguistics by extending its theoretical conceptions of combinability, syntagmatic relations and combinatorial properties, the nature of attributive adjectives and their lexicographic elaboration.

The practical importance of the research is that its methodological framework for analyzing and interpreting adjective-noun collocations in the Ukrainian language of the 16th-18th centuries can be 
used for studying other types of word groups as well as in contrastive typology. The research offers novel contributions which can be used for preparing a fundamental paper generalizing the combinability of language units in the old Ukrainian language, for writing textbooks and study manuals on the historical lexicology and lexicography of the Ukrainian language, for compiling a combinatorial dictionary of the 16th-18th-century Ukrainian language, as well as for teaching lexicology and lexicography, the history of the Ukrainian language, and courses for philology majors at higher educational institutions.

\section{REFERENCES}

[1] Дидик-Меуш Г. Комбінаторика в украӥнській мові XVI-XVIII століть: теорія, практика, словник. Інститут українознавства ім. І. Крип'якевича, Наукове товариство ім.Шевченка, Львів, 2018.

[Dydyk-Meush H. Kombinatoryka v ukrainskii movi XVI-XVIII stolit: teoriia, praktyka, slovnyk. Instytut ukrainoznavstva im. I. Krypiakevycha, Naukove tovarystvo im. Shevchenka, Lviv, 2018.]

Address: Vasyl Greshchuk, Vasyl Stefanyk Precarpathian National University, 57 Shevchenko St., IvanoFrankivsk, 76025 Ukraine.

E-mail: ukrinst.pu.if@gmail.com

Received: April 27, 2020; revised: November 22, 2020.

Грещук Василь. Нове слово в теорії і практиці історичної лексикографії. Журнал Прикарпатського університету імені Василя Стефаника, 7 (2) (2020), 117-120. 